\title{
Marx for Poles
}

\author{
Michal Buchowski ${ }^{1,2}$
}

Published online: 9 April 2015

(c) The Author(s) 2015. This article is published with open access at Springerlink.com

There is no denying the fact that much has been written on Marx! In the view of the fact that Kevin B. Anderson has already contributed significantly to this literature, one could have expected that his new book might repeat some of his arguments or cast them in just yet another fashion. The continuity of his interest in the intellectual production of Marx and Engels is undoubtedly visible, and among the impressively numerous other works, he refers also to his own previous publications. However, in this book, Anderson focuses on two major issues viewed from Marx's own nineteenth century London perspective: first, on regions/societies/countries significantly different from the European ones, such as China, India, Russia or Algeria, considered to be 'non-Western precapitalist societies' and second, on countries functioning in nineteenth century at the peripheries of the core capitalist system, such as the USA, Ireland, Russia and Poland. All of them can be also grouped according to the degree they were integrated into the global capitalist order and, often concurrently, the colonial arrangement.

Two major topics are followed in the book. The first is the problem of whether the evolution of the European or non-European societies was multilinear and unilinear, especially the question of if, whether and how capitalism should modernize the latter before they could become sites of resistance to the capital. The second is the emancipation of nations, nationalities and ethnic groups in different regions of the world, but especially in Poland, Ireland and the USA. Only on the surface do these two topics seem to be loosely related. As Anderson convincingly shows, the question of national and social liberation is closely intertwined in Marx's

Michal Buchowski

mbuch@amu.edu.pl

1 Adam Mickiewicz University in Poznan, Poznan, Poland

2 European University Viadrina, Frankfurt, Germany 
view of progress toward social justice and freedom of people, at least in the form he imagined them. Initially very critical of the revolutionary potential of the groups living on the margins of the capitalist universe, he gradually changed his mind. In fact, societies exercising traditional or communal forms of life appeared to him as sites where resistance can emerge. In this way, they can become an important part of the opposition toward the exploitative order, an element of the global anti-capitalist alliance. It is the importance of these issues for the whole intellectual project of Marx and Engels that Anderson wants to demonstrate, and I think he does it successfully.

One of the chapters that addresses the above-mentioned issues directly and highlights them extensively is 'Russia and Poland: The Relationship of National Emancipation to Revolution.' Most opinions on this problem were expressed by Marx in numerous newspaper polemics, political disputes and public gatherings that stretched over half a century. The political climate had been changing, and Marx was accordingly correcting his views, although some basic assessments remained unchanged. Anderson collects them and puts in both chronological and thematic order as well as within a conceptual framework for the whole book. It was an immense task that he has managed very well.

In Marx's and partly in Engels' account, the picture was quite dichotomous, black and white. There was bad Russia that oppressed good Poland, and there was a spirited nation of Poles who fought against the most conservative regime on the continent. There is no doubt that the Russian Empire functioned in the nineteenth century as a warden of a political and social order that was very much distant from what revolutionaries imagined it should be. The Tsar and his or her (when Catherine the Great II-whose power that lasted till 1796-is considered) troops were seen as a major obstacle to the ability of emancipatory movements to emerge and thrive. As Marx put it, and Anderson cites him, Russia was 'the greatest enemy of all advance' (p. 43). This strong political vision prompted Marx to use all possible stereotypes in his description of Russia and Russian society. She represented to him a form of Oriental despotism that was applied equally harshly in internal and international affairs. Marx credits this characteristic to 'the bloody mire of Mongolian slavery' (p. 47). Therefore, Russia exercised aggressive policy toward neighbors like Poland and Turkey, Chechens and Tatars, but also western states. Russian peasants living in traditional communities are inept, impotent and incapable of self-emancipation. As already mentioned, it was only around 1870 that Marx changed his attitude toward the revolutionary potential of the exploited poor.

It is clear that in his revolutionary fervor Marx was uncritically a slave of ethnocentric, western stereotypes about Russia and her 'masses.' Russian peasants represented for him little more than 'sack of potatoes,' to use here the term employed by the Soviet writer Maxim Gorki (who borrowed it from Marx's '18th Brumaire,' but took it out of context). We can say that his vocabulary fits neatly into all the categories that Said (1978) identified for orientalism. This general weakness of Marx - that he was subject to orientalizing reasoning - is dutifully identified and criticized by Anderson. He finds also examples of ahistoricism represented by scholars citing Marx in their interpretation of the Soviet policy which was viewed as a protraction of the post-Mongolian, post-tsarist and Asiatic mode of doing politics. 
One can add Milan Kundera's famous essay on kidnapped Europe published in 1984 in the New York Times Book Review (1984), ${ }^{1}$ in which he described the Soviet regime in exactly the same way as Marx did. Similar to Marx, Kundera's motive was laudable-liberation of Central European Soviet satellite states from the political dependency on an authoritarian system-but his reasoning had similarly lapsed into orientalizing argumentation. Not surprisingly, Russia's aggressive politics today toward Chechenya, Georgia, Moldova and Ukraine is often interpreted in terms of frozen cultural features drifting on in history independently of changing economic, geopolitical, social and cultural contexts. The Balkan conflicts in the 1990s were also construed as a re-emergence of ancient tribal hatreds. For a long time, South Slavs also appeared to Marx to be backward. Apparently, he was often subject to this mode of thinking, always stereotyping and exoticizing people in the East.

However, Poland was always for Marx a counterbalance to Russian and other conservative forces in Europe and to despotic regimes. Poles presented a counterexample to Russians and other Slavic serfs. He strongly opposed the partitions of the Nobles Republic led by Russia and relentlessly supported the Polish resistance and the series of uprisings in 1830, 1846, 1848 and 1863. Polish sovereignty aspirations were seen in the framework of European politics. His knowledge of international relations as well as the internal sociopolitical context of Polish regions was genuinely impressive. In Marx's view, empires thwarted independence attempts in order to keep both the political and the social status quo. Marx was critical of Napoleon's politics, which the Poles wholeheartedly supported and for which they had shed their blood. He accused the French emperor of preying on people who were desperately seeking freedom. The signs of solidarity expressed by the English were, according to Marx, superficial and merely symbolic. The Germans should have had a lively interest in Polish liberation. In remaining disinterested, Europeans were losing the opportunity to make advancements in their own liberation. All progressive people should have therefore supported Poland in the name of freedom and social liberation. Political and social goals were tightly connected. As Anderson rightly notes, Marx seemed to be arguing that 'unless democratic and class struggles could link up with those of oppressed nationalities, both would fail to realize fully their aims, if not go down to defeat' (p. 72).

Anderson tracks in a masterly way all the nuances of Marx's, and partly of Engels', thoughts and statements on Russia and Poland as well as Central and Southeastern Europe. He tracks Marx's analysis of the winding ways of politics and social problems, the arguments waged by him against opponents and the real fervor with which he engaged the Polish case. His combativeness made him an ambassador of Polish independence. In this context, it may seem surprising that Marx is so strongly rejected by Poles today, as he was also by the majority of ordinary wo/man from the street in the communist past. His name has been directly associated with the political regime and has become metonymically identified with the vulgar

\footnotetext{
${ }^{1}$ First version of this essay was published in the French journal Le Débat under the title 'Un occident kidnappé.'
} 
communist ideology officially called 'Marxist.' Such a political concoction of Marxism and Leninism legitimized the authoritarian and largely rejected (at least at the ideological and declarative level) system. Thus, Marx functioned as the 'intellectual' patron of an unwanted sociopolitical order. His function as the regime's godfather eclipsed his role as a protagonist of the Polish case. This is the major reason why, a quarter of a century after the demise of the 'really existing socialism' in Central and Eastern Europe, in particular in Poland, Marx and Marxist ideas are so unpopular. Leftist thought is ostracized and marginalized in public discourses.

What can partly be problematized in Anderson's entire exercise is the issue of 'the margins.' He explains that the book is about the margins of the capitalist system in the nineteenth century, and this is a fair distinction, although drawing a line is an arbitrary attempt. Hence, Poland is treated as being at the margin. The point I want to make is that such a unified treatment shrouds the commonly known fact that the country was divided between three different empires, and at least one of them, namely Prussia, in contrast to Russia and to large extent Austria, has not been considered as being on the margins of the capitalist system. Parts of Poland which Marx had in mind and mentioned explicitly in his writings were parts of Prussia, e.g., Gdańsk Pomerania and Grand Duchy of Poznań. Both were not as industrialized as western parts of Germany, but still the distinction between them and Galicia, or the nominal Kingdom of Poland with the capital in Warsaw that was part of Russian Empire, should be mentioned. Perhaps this is the only nuance that Anderson fails to emphasize. It is an important issue in the view of the book's subject and title. The Polish fight for independence stretched over empires' borders, disregarding the fact that the social and individual status of peasants, agricultural workers and (the rather few) industrial workers, was substantially different. Peasants were freed from serfdom in Prussia in 1807 (between 1811 and 1823 in practice), in Galicia in 1848 and in the Russian-ruled Kingdom of Poland as late as in 1864. In the perspective of 'Marx's century,' the difference was crucial and had critical social consequences. However, these dissimilarities in the various parts of the state did not prevent national ideas from being alive across borders, in very differently arranged polities. Of course, these ideas had been undergoing transformations from noble's civic nationalism to Herderian folk, popular, ethnic nationalism. The peasant question (and peasants were for long reluctant to support the national cause; in 1846 they defied violently their 'Polish landlords' in Galicia) was one of the most hotly discussed issues (cf. Stuart-Halstead 2001), but the ultimate outcome partly confirmed Marx's diagnosis that the juncture of national and class issues is vital for any critical analysis. On the one hand, the overarching potential of nationalism for concealing the class relation was shown and nationalism took an upper hand. On the other hand, Marx's hope that national liberation would advance class liberation was not entirely fulfilled.

Open Access This article is distributed under the terms of the Creative Commons Attribution 4.0 International License (http://creativecommons.org/licenses/by/4.0/), which permits unrestricted use, distribution, and reproduction in any medium, provided you give appropriate credit to the original author(s) and the source, provide a link to the Creative Commons license, and indicate if changes were made. 


\section{References}

Kundera, Milan. 1984. 'The tragedy of Central Europe' (Trans. from French by E. White) The New York review of books, vol. 31, no. 7, 33-38.

Said, Edward. 1978. Orientalism: Western conceptions of the orient. London: Pantheon Books.

Stauter-Halstead, Kelly. 2001. The nation in the village: The genesis of Polish national identity in Austrian Poland. 1848-1914. Ithaca: Cornell University Press. 